\title{
Strategi Pengembangan Usaha Ternak Sapi Potong di Kecamatan Lau Kabupaten Maros
}

\author{
Rusni Fitri Y. Rusman ${ }^{1}$, Andi Hamdana ${ }^{2}$, Abdullah Sanusi ${ }^{3}$ \\ ${ }^{1}$ Fakultas Pertanian, Peternakan dan Kehutanan Universitas Muslim Maros \\ ${ }^{2}$ Fakultas Pertanian, Peternakan dan Kehutanan Universitas Muslim Maros \\ ${ }^{3}$ Fakultas Ekonomi dan Bisnis Universitas Hasanuddin \\ rusnifitri@umma.ac.id
}

\begin{abstract}
Abstrak: Populasi ternak, infrastuktur peternakan dan daya dukung pakan merupakan beberapa kriteria parametrik dalam penentuan sentra peternakan sapi potong. Kecamatan Lau merupakan salah satu kecamatan di Kabupaten Maros yang masih didominasi peternakan rakyat di mana jumlah kepemilikan ternak hanya berkisar 2 hingga 5 ekor. Kepemilikan dan peternakan sapi potong masih merupakan usaha sampingan di mana bertani sawah padi merupakan pekerjaan utama masyarakat. Dalam upaya mengoptimalkan peternakan sapi potong perlu diketahui kekurangan dan kelebihan serta peluang dan ancaman yang dihadapi peternak dalam menjalankan usaha peternakan sapi potong. Pemilihan lokasi dilakukan secara sengaja (purposive sampling) yang didasarkan bahwa daerah tersebut merupakan salah satu pengembangan sapi potong. Penentuan sampel akan dilakukan secara acak (random sampling) terhadap petani dan snowballing sampling terhadap stakeholders yang terkait dengan peternakan sapi potong dalam hal ini pemerintah daerah selaku pengambil kebijakan dan para pelaku usaha. Hasil penelitian ini menunjukkan bahwa skor matriks IFE adalah 1,43 dan EFE adalah 1,66 di mana kedua titik ini berada pada kuadran 1 matriks SWOT. Dalam penentuan strategi terdapat 3 alternatif strategi S-O, 4 alternatif $\mathrm{W}-\mathrm{O}$ serta strategi S-T dan W-T masing-masing 2. Alternatif strategi yang dihasilkan mendukung pada strategi yang agresif dalam mendorong pengembangan usaha ternak sapi potong di Kecamatan Lau Kabupaten Maros.
\end{abstract}

Kata Kunci: Sapi Potong; Matriks IFE\&EFE; Analisis SWOT; Kabupaten Maros

Abstract: Livestock population, infrastructure and feed carrying capacity are some of the parametric criteria in determining the center of beef cattle farming. Lau Subdistrict is one of the sub-districts in Maros Regency which is still dominated by smallholder farms where the number of livestock ownership ranges from only 2 to 5 cattle. Ownership and beef cattle farming is still a side business where rice farming is the main job of the community. In an effort to optimize beef cattle breeding, it is necessary to know the advantages and disadvantages as well as the opportunities and threats faced by farmers in running a beef cattle business. The location selection was carried out purposively based on the fact that the area is one of the development of beef cattle. Random sampling technique is used in determining which farmers are questioned and snowballing sampling to stakeholders related to beef cattle farming, in this case the local government as policy makers and business actors. The results indicate that the IFE matrix score is 1.43 and EFE is 1.66 where these two points are in quadrant 1 of the SWOT matrix. In determining the strategy, there are 3 alternatives $S-O$ strategies, $4 W-O$ alternatives and $S-T$ and $W-T$ strategies respectively 2. The goals of alternative strategies support an aggressive strategy in encouraging the development of beef cattle business in Lau District, Maros Regency.

Keywords: Beef Cattle; IFE \& EFE Matrix; SWOT Analysis; Maros Regency

\section{PENDAHULUAN}

Industri sapi potong memiliki peran penting dalam meningkatkan asupan protein masyarakat Indonesia. Kebutuhan daging sapi dari tahun ke tahun terus meningkat seiring dengan pertumbuhan jumlah penduduk serta kesadaran akan kecukupan protein sedangkan sebagian 
besar budidaya ternak sapi potong masih dilakukan secara tradisional. Lebih dari $90 \%$ usaha peternakan sapi potong di Indonesia masih berskala kecil dengan model peternakan rakyat, modal lemah serta masih bersifat usaha sampingan (Yusdja \& Ilham, 2006). Padahal jika dilihat dari pangsa konsumsi, usaha ternak sapi potong memiliki potensi yang dapat meningkatkan kehidupan ekonomi peternak dengan meningkatkan produksi untuk menutupi volume impor sapi potong dan produk olahannya yang mencapai 600-700 ekor/tahun (Mayulu dkk, 2010).

Kabupaten Maros adalah salah satu daerah yang masuk menjadi proritas pengembangan usaha ternak sapi potong di Sulawesi Selatan. Kabupaten Maros merupakan salah satu sentra pengembangan sapi potong selain Kabupaten Bone, Bulukumba, Gowa, Pinrang, Sidrap, Sinjai dan Wajo yang memiliki daya dukung pakan yang cukup untuk pengembangan usaha ini. Walaupun ditunjang dengan berbagai aspek, seperti daya dukung pakan dan bibit unggul, populasi ternak di Kabupaten Maros mengalami penurunan hingga 5 \%. Berdasarkan data dari Badan Pusat Statistik Kabupaten Maros (2018), populasi ternak besar di tahun 2016 adalah 83.619 ekor sedangkan di tahun 2017 mengalami penurunan menjadi 80.540 ekor.

Usaha peternakan sapi potong di Kecamatan Lau umumnya masih didominasi oleh peternakan rakyat di mana jumlah kepemilikan ternak hanya berkisar 2 hingga 5 ekor saja. Hal ini dikarenakan beternak sapi potong bukan merupakan usaha utama mereka melainkan bertani sehingga cara pengelolaan usaha ternak sapi potong ini masih dilakukan dalam skala kecil dan berpencar-pencar. Permasalahan lain yang dihadapi adalah peternak masih cenderung melakukan pengembangbiakan ternak sapi dengan pola tradisional (kawin alam) sehingga penggunaan teknologi Inseminasi Buatan (IB) masih kurang optimal.

Potensi sumber daya alam dan sumber daya manusia di Kecamatan Lau cukup potensial dikembangkan dengan adanya pasar hewan dan letak geografis yang strategis karena akses ke Makassar sebagai Ibu Kota Provinsi cukup dekat. Melihat kondisi tersebut, maka daerah ini masih mempunyai peluang untuk dilakukan pengembangan lebih lanjut. Berdasarkan uraian tersebut maka tujuan dari penelitian ini adalah dapat mengidentifikasi beberapa masalah disertai faktor-faktor internal dan eksternal apa saja yang mempengaruhi pengembangan usaha ternak sapi potong di Kecamatan Lau lalu memilih strategi yang tepat bagi peternak dalam menjalankan usaha ternak sapi potong

\section{TINJAUAN PUSTAKA}




\subsection{Tinjauan Umum Ternak Sapi Potong}

Jenis sapi potong yang banyak dikembangkan di Indonesia adalah sapi bali yang merupakan ternak sapi potong andalan Indonesia. Sapi bali merupakan sapi hasil keturunan dari sapi liar yang sudah mengalami proses yang cukup lama. Sapi bali memiliki bulu halus, pendek-pendek dam mengkilap. Pada saat muda warna bulunya yang coklat akan berubah menjadi hitam. Sapi bali dapat mencapai bobot badan jantan dewasa 350-400 kg dan betina dewasa antara 250-300 kg. Hewan ini memiliki persentase karkas yang kadar lemaknya sedikit serta perbandingan tulang sangat rendah. Selama ini sapi potong dijual untuk memenuhi kebutuhan pasar local seperti rumah tangga, hotel, restaurant, indutrsi pengolahan daging serta pasar atau pulau terutama untuk pasar kota-kota besar (Utari, 2015)

Menurut Mariyono et al (2010) bahwa sapi potong merupakan salah satu komponen usaha yang cukup berperan dalam agribisnis pedesaan, utamanya dalam sistem integrase dengan subsektor pertanian lainnya, sebagai rantai biologis dan ekonomis sistem usaha tani. Terkait dengan penyediaan pupuk, maka sapi dapat berfungsi sebagai "pabrik kompos". Seekor sapi dapat menghasilkan kotoran sebanyak 8-10 kg/hari yang apabila diproses akan menjadi 4-5 kg pupuk organik. Potensi pupuk organic ini diharapkan dapat dimanfaatkan secara optimal untuk mempertahankan kesuburan lahan, melalui siklus unsur hara secara sempurna.

Peternakan sapi potong merupakan suatu industri di bidang agribisnis dengan rantai kegiatannya tidak hanya terbatas pada kegiatan on farm tetapi juga meluas hingga kegiatan di hulu dan hilir sebagai unit bisnis pendukungnya. Di hulu, produksi bibit, pakan, sapronak merupakan kegiatan besar yang sangat mendukung tercapainya produktivitas sapi potong yang hebat sementara di hilir penanganan pascapanen memegang peranan yang sangat kuat untuk meningkatkan kualitas dan nilai tambah (value added) bagi daging sapi. Kegiatankegiatan tersebut perlu dilakukan secara integritas agar terbentuk sistem industri peternakan sapi potong yang kuat (Rianto dan Purbowati, 2009)

\subsection{Strategi Pengembangan}

Dalam Tafakrenanto et al (2016) menyatakan bahwa sentra peternakan sapi potong Nasional merupakan potensi untuk pengembangan kawasan peternakan sapi potong Nasional. Sentra peternakan sapi potong Nasional ditentukan secara parametrik dengan pembobotan terhadap : daya dukung pakan, populasi ternak, infrastruktur peternakan, status penyakit ternak, rumah tangga peternak, kelembagaan peternakan dan dukungan masterplan. 
Dukungan pemerintah daerah terhadap pengembangan peternakan menjadi pertimbangan dalam menentukan sentra peternakan. Dukungan pemerintah daerah antara lain berupa masterplan/renaksi peternakan. Hal ini menunjukkan pemerintah daerah tersebut serius dalam mengelola pengembangan peternakan.

Pengembangan sapi potong memerlukan pengelompokan basis wilayah yang disesuaikan dengan daya dukung (carrying capacity) sebagai model pengembangan ke depan. Pada umumnya daerah yang menjadi produsen utama daging di Indonesia berupa usaha penggemukan selain pembibitan dengan pola intensif dengan basis pengembangan usaha difokuskan pada industri hilir. Potensi pakan terintegrasi dengan tanaman pangan, perkebunan dan kehutanan dan sudah mengarah pada usaha semikomersial. Pemetaan wilayah pengembangan usaha (sumber pertumbuhan baru) dengan pola pembibitan maupun penggemukan diperlukan untuk mendukung peningkatan populasi ternak. Selain itu, area penggembalaan, sumber daya manusia, teknologi tepat guna, sarana pendukung dan potensi pasar merupakan aspek yang menjadi pertimbangan (Priyanto, 2011)

\subsection{Analisis SWOT}

Analisis SWOT adalah identifikasi berbagai faktor secara sistematis untuk merumuskan strategi suatu usaha (organisasi). Analisis ini didasarkan pada kenyataan atau logika yang dapat memaksimalkan kekuatan (strength) dan kelemahan (weakness) namun secara bersamaan dapat menimbulkan peluang (opportunity) dan ancaman (threat). Analisis SWOT adalah metode perencenaan strategis yang digunakan untuk mengevaluasi kekuatan (strengths), kelemahan (weakness), peluang (oppurtunities) dan ancaman (threats) dalam suatu proyek atau suatu spekulasi bisnis. Keempat faktor itulah yang membentuk akronim SWOT (strengths, weakness, opportunities dan threats). Proses ini melibatkan penentuan tujuan yang spesifik dari spekulasi bisnis atau proyek dan mengidentifikasi faktor internal dan eksternal yang mendukung dan yang tidak dalam mencapai tujuan tersebut (Rangkuti, 2009)

Tahapan dalam metode skoring adalah : a) menentukan faktor-faktor internal atau eksternal dalam kolom1, b0 hitung rating (dalam kolom 1 dijumlahkan kemudian dibagi jumlah total keseluruhan) untuk masing-masing faktor dengan memberikan skala mulai dari 1 (sangat kurang) dampai dengan 6 (sangat baik), berdasarkan pengaruh faktor tersebut terhadap kondisi wilayah yang bersangkutan, c) hitung bobot (dalam kolom 1 dijumlahkan kemudian dibagi jumlah total keseluruhan) untuk masing-masing faktor dengan memberikan 
skala mulai 1 (tidak penting) sampai dengan 4 (sangat penting) berdasarkan penilaian urgensi penanganan pengembangan usaha ternak sapi potong, (semua bobot tersebut jumlahnya tidak boleh melebihi skor total 1,00), d) Hitung rata-rata tertimbang kelemahan (weakness) untuk mendapatkan nilai (x) (Purnomo et al, 2017)

\section{METODE PENELITIAN}

Metode yang digunakan dalam penelitian ini adalah analisis deksriptif di mana pengumpulan data yang dilakukan untuk menjawab permasalahan yang ada dan dilakukan dalam bentuk survei dan wawancara. Teknik pengambilan sampel dilakukan dengan menggunakan teknik porpusive sampling. Jenis data yang digunakan terdiri dari data primer dan sekunder sedangkan sumber data berasal dari internal dan eksternal Dinas Pertanian dan Ketahanan Pangan Bidang Peternakan Kabupaten Maros. Data tersebut diperoleh melalui observasi langsung, wawancara, kuisioner dan studi pustaka.

Analisis SWOT

Analisis SWOT merupakan alat yang dgunakan dalam mengembangkan strategi yang efektif. Terdapat 4 komponen strategi SWOT [9] yaitu:

1. Strategi SO, strategi yang mengoptimalkan faktor kekuatan dan memanfaatkan peluang

2. Strategi ST, strategi yang mengoptimalkan faktor kekuatan dan mengatasi ancaman

3. Strategi WO, strategi yang memanfaatkan faktor peluang dan meminimalkan kelemahan

4. Strategi WT, strategi yang bersifat defensive dan berupaya meminimalkan kelemahan serta menghindari ancaman

Tahapan yang dilakukan dalam analisis data adalah:

1. Analisis IFE (Internal Factor Evaluation) dan EFE (External Factor Evaluation) yang digunakan untuk mengidentifikasi faktor-faktor lingkungan yang berpengaruh

2. Matriks SWOT (Strengths-Weakness Opportunities-Threats) digunakan untuk merumuskan alternative strategi

4 HASIL DAN DISKUSI

4.1. Analisis Matriks IFE (Internal Factor Evaluation) dan EFE (External Factor Evaluation) Usaha Ternak Sapi Potong di Kecamatn Lau 
Analisis IFE dan EFE dilakukan untuk mengidentifikasi faktor internal dan eksternal pada peternakan sapi potong di Kecamatan Lau. Untuk mendapatkan hasil identifikasi tersebut dilakukan dengan menanyakan beberapa poin pertanyaan kepada peternak dan stakeholder di daerah tersebut. Identifikasi tersebut termasuk di dalamnya mengenai manajemen pemeliharaan ternak sapi potong, pakan ternak, reproduksi dan penanganan kesehatan serta pemasaran sapi potong. Hasil dari identifikasi tersebut kemudian ditempatkan pada kolom-kolom yang ada pada penialian analisis SWOT yaitu kekuatan, kelemahan, peluang serta ancaman. Untuk mengetahui hasil dari skor tiap faktor strategi eksternal dan internal tersebut maka dilakukan perhitungan rating dan bobot seperti yang ditampilkan pada tabel-tabel di bawah ini :

Tabel 1. Matriks IFE Usaha Ternak Sapi Potong

\begin{tabular}{|c|c|c|c|c|}
\hline No & Strenghts (S) & Bobot & Rating & Skor \\
\hline 1 & Kemudahan dalam pemberian pakan & 0,27 & 5 & 1,36 \\
\hline 2 & Adanya pencatatan reproduksi & 0,18 & 3 & 0,55 \\
\hline 3 & Biaya Modal relatif rendah & 0,27 & 3 & 0,82 \\
\hline \multirow[t]{2}{*}{4} & Kemudahan pemasaran ternak & 0,27 & 4 & 1,09 \\
\hline & Total Strenghts & $\mathbf{1 , 0 0}$ & & 3,82 \\
\hline No & Weaknesses (W) & Bobot & Rating & Skor \\
\hline 1 & Usaha ternak sapi potong sebagai usaha sampingan & 0,23 & 3 & 0,69 \\
\hline 2 & Pendidikan peternak yang masih relatif rendah & 0,15 & 3 & 0,46 \\
\hline 3 & Kurangnya jumlah sapi yang diternakkan & 0,23 & 2 & 0,46 \\
\hline 4 & Kurangnya minat beternak & 0,23 & 2 & 0,46 \\
\hline 5 & Penyakit hewan (cacingan) & 0,15 & 2 & 0,31 \\
\hline & Total Weakness & 1,00 & & 2,38 \\
\hline
\end{tabular}

Sumber : Data Primer, 2020

Berdasarkan tabel 1 diketahui bahwa ada empat faktor kekuatan dan ada lima faktor kelemahan dalam identifikasi IFE atau faktor internal pada usaha ternak sapi potong di Kecamatan Lau. Di mana total skor faktor Kekuatan (Strengths) adalah 3,82 dan total skor faktor Kelemahan (Weakness) adalah 2,38 sehingga hasil selisih antara kekuatan dan kelemahan bernilai positif 1,43 . Hasil ini menunjukkan bahwa faktor kekuatan yang dimiliki usaha ternak potong lebih besar dibandingkan kelamahannya.

Tabel 2. Matriks EFE Usaha Ternak Sapi Potong

\begin{tabular}{clccc}
\hline No & Oppurtunities $(\mathbf{O})$ & Bobot & Rating & Skor \\
\hline 1 & Pemberian obat-obatan dan vaksin gratis dari pemerintah & 0,27 & 4 & 1,09 \\
2 & Pengecekan kebuntingan dan inseminasi buatan & 0,27 & 4 & 1,09 \\
3 & Penyuluhan peternakan & 0,18 & 3 & 0,55 \\
4 & Infrastruktur yang memadai & 0,27 & 5 & 1,36
\end{tabular}


Total Opportunities

\begin{tabular}{|c|c|c|c|c|}
\hline No & Treaths $(\mathbf{T})$ & Bobot & Rating & Skor \\
\hline 1 & Adanya alih fungsi lahan untuk pertanian & 0,43 & 3 & 1,29 \\
\hline 2 & Keterbatasan tenaga kerja & 0,29 & 2 & 0,57 \\
\hline \multirow[t]{2}{*}{3} & Persaingan dengan usaha lainnya (padi) & 0,29 & 2 & 0,57 \\
\hline & Total Treaths & 1,00 & & 2,43 \\
\hline
\end{tabular}

Sumber : Data Primer, 2020

Berdasarkan tabel 2 diatas diketahui bahwa ada empat faktor Peluang dan ada 3 faktor Ancaman dalam identifikasi EFE atau faktor eksternal pada usaha ternak sapi potong di Kecamatan Lau. Di mana total skor faktor Peluang (Opportunities) adalah 4,09 dan total skor faktor Ancaman (Treaths) adalah 2,43 sehingga hasil selisih antara kekuatan dan kelemahan bernilai positif 1,66. Hasil ini menunjukkan bahwa faktor peluang yang dimiliki usaha ternak potong lebih besar dibandingkan ancamannya.

\subsection{Matriks SWOT}

Setelah melakukan perhitungan pada tabel IFE dan EFE maka hasil rata-rata dari kedua tabel tersbut akan digambarkan pada grafik analisis SWOT serta dijabarkan pada anaaliss matriks SWOT di bawah ini :

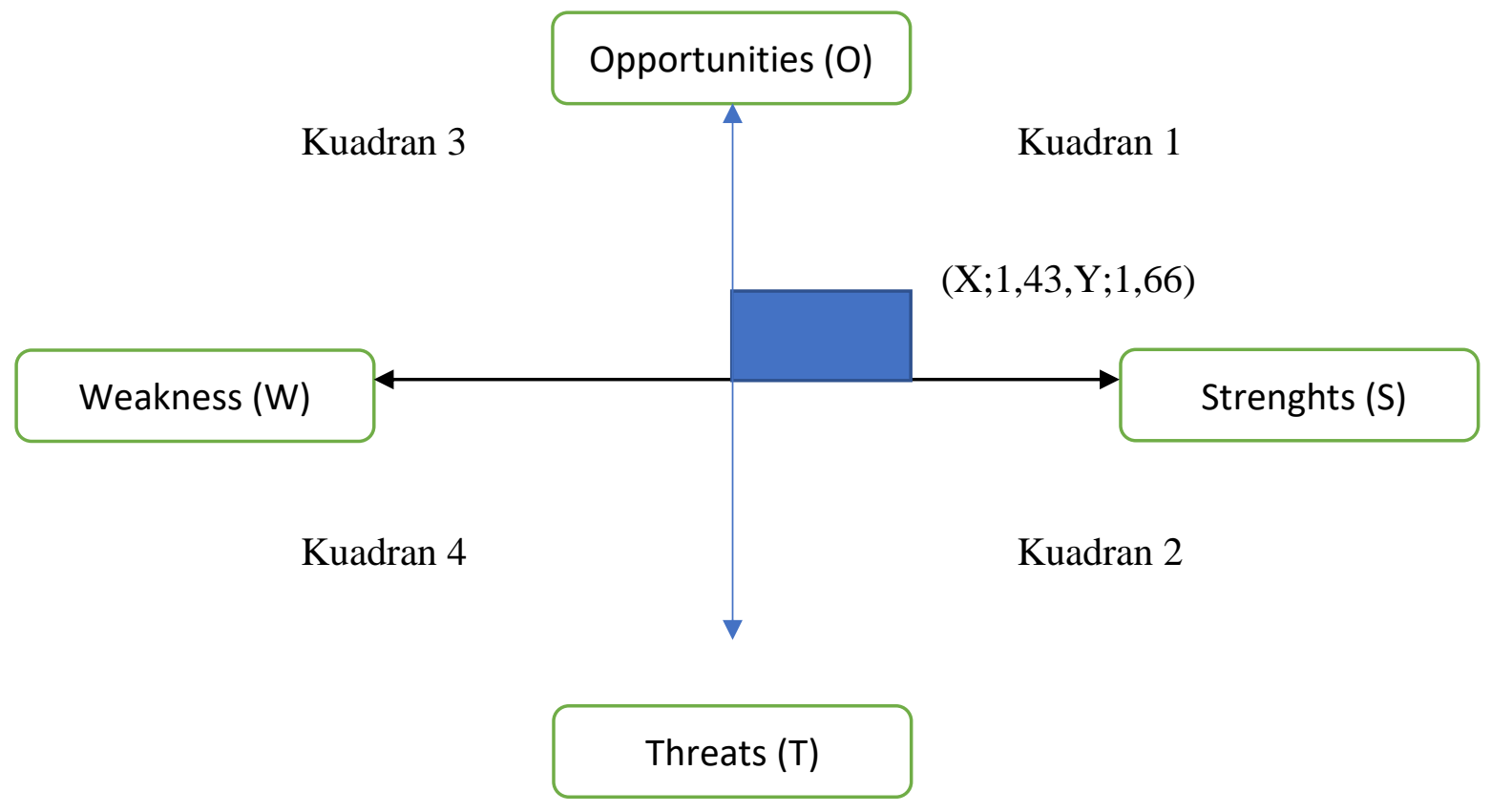

Gambar 1. Kuadran Analisis SWOT

Pada Gambar 1 memperlihatkan bahwa hasil dari IFE (X) dan EFE (Y) berada pada kuadran 1. Di mana hal ini menunjukkan bahwa usaha ternak sapi potong memliki kombinasi kekuatan dan peluang yang dapat dimanfaatkan dalam pengembangan kedepannya. 
Tabel 3. Analisis Matriks SWOT Pengembangan Usaha Ternal Potong di Kecamatan Lau Kabupaten Maros

\begin{tabular}{|c|c|c|}
\hline $\begin{array}{r}\text { Faktor - } \mathrm{F} \\
\text { In }\end{array}$ & $\begin{array}{l}\text { 1. Kemudahan } \\
\text { pemberian pakan } \\
\text { 2. Adanya pencatatan } \\
\text { reproduksi } \\
\text { 3. Biaya modal realtif rendah } \\
\text { 4. Kemudahan pemasaran } \\
\text { ternak }\end{array}$ & $\begin{array}{l}\text { 1. Usaha ternak sapi potong } \\
\text { sebagai usaha sampingan } \\
\text { 2. Pendidikan peternak yang } \\
\text { masih relatif rendah } \\
\text { 3. Kurangnya jumlah sapi yang } \\
\text { diternakkan } \\
\text { 4. Kurangnya minat beternak } \\
\text { 5. Penyakit ternak (cacingan) }\end{array}$ \\
\hline $\begin{array}{l}\text { Opportunities }(\mathrm{O}) \\
\text { 1. Pemberian obat-obatan } \\
\text { dan vaksin gratis dari } \\
\text { pemerintah } \\
\text { 2. Pengecekan kebuntingan } \\
\text { dan inseminasi buatan } \\
\text { 3. Penyuluhan peternakan } \\
\text { 4. Infrastruktur yang } \\
\text { memadai }\end{array}$ & $\begin{array}{l}\text { Strategi } \mathrm{S}-\mathrm{O} \\
\text { 1. Memaksimalkan potensi } \\
\text { lahan dalam pemberian } \\
\text { pakan produktif dan lokasi } \\
\text { penggembalaan } \\
\text { 2. Memberikan informasi } \\
\text { mengenai harga jual ternak } \\
\text { dan pasar potensial yang } \\
\text { menguntungkan } \\
\text { 3. Memberikan layanan } \\
\text { inseminasi buatan terhadap } \\
\text { betina-betina produktif }\end{array}$ & $\begin{array}{l}\text { Strategi W-O } \\
\text { 1. Memberikan pelatihan } \\
\text { dalam pengelolaan } \\
\text { manajemen ternak sapi } \\
\text { potong } \\
\text { 2. Meningkatkan jumlah } \\
\text { anakan sapi dengan } \\
\text { menambah frekuensi } \\
\text { kelahiran melalui IB } \\
\text { 3. Memnbuat penyuluhan } \\
\text { khusus terkait penyakit } \\
\text { hewan (cacingan) } \\
\text { 4. Menjadikan usaha ternak } \\
\text { sapi sebagai usaha utama } \\
\text { yang menjanjikan }\end{array}$ \\
\hline $\begin{array}{l}\text { Treaths (T) } \\
\text { 1. Keterbatasan tenaga } \\
\text { kerja } \\
\text { 2. Persaingan dengan usaha } \\
\text { lainnya (padi) } \\
\text { 3. Adannya alih fungsi } \\
\text { lahan untuk pertanian }\end{array}$ & $\begin{array}{l}\text { Strategi S-T } \\
\text { 1. Meningkatkan efektifitas } \\
\text { penggunaan lahan untuk } \\
\text { ternak sapi potong } \\
\text { 2. Kerjasama dengan } \\
\text { pemerintah daerah dalam } \\
\text { meningkatkan produktivitas } \\
\text { usaha ternak potong }\end{array}$ & $\begin{array}{l}\text { Strategi } \mathrm{W}-\mathrm{T} \\
\text { 1. Memperkuat peran } \\
\text { kelompok ternak lokal } \\
\text { 2. Mendorong kebijakan } \\
\text { pemerintah dalam } \\
\text { pengembanagn usaha ternak } \\
\text { sapi potong }\end{array}$ \\
\hline
\end{tabular}

Pada tabel menunjukkan beberapa empat strategi yang didapatkan yang merupakan hasil dari gabungan faktor internal dan eksternal. Strategi S-O (Strength-Opportunity) merupakan strategi yang menggunakan kekuatan sebagai faktor internal untuk memnafaatkan peluang yang ada. Strategi yang didapatkan yaitu dengan memaksimalkan potensi lahan, memberikan informasi mengenai harga jual ternak serta memberikan layanan inseminasi buatan terhadap betina-betina produktif. Purnomo (2017) menjelaskan bahwa pemnafaatan 
lahan dalam sistem tanaman-ternak dapat dilakukan dalam pengembangan pakan serta mengefektifkan jaringan pemasaran dalam memenuhi permintaan pasar.

Strategi W-O (Weakness-Opprtunity) merupakan strategi yang menggunakan peluang yang ada untuk meminimalkan kelemahan. Beberapa alternatif strategi yaitu memberikan pelatihan dalam pengelolaan manajemen ternak sapi potong, meningkatkan jumlah anakan sapi dengan menambah frekuensi kelahiran melalui IB, membuat penyuluhan khusus terkait penyakit cacingan serta menjadikan usaha ternak sapi sebagai usaha utama yang menjanjikan. Berdasarkan data responden, mayoritas responden/peternak hanya berpendidikan sekolah dasar dengan keterampilan minim mengenai pengelolaan manajemen ternak sapi potong. Karim (2019) pelatihan bagi pekerja dibutuhkan dalam meningkatkan pengetahuan bagi pemilik usaha atau tenaga kerja yang rata-rata berpendidikan sekolah dasar.

Strategi S-T (Strenght-Threat) merupakan strategi yang mengandalkan kekuatan untuk menutup kemungkinan ancaman yang dapat mengganggu perkembangan potensi usaha ternak sapi potong. Alternatif strategi yang bisa ditempuh yaitu dengan meningkatkan efektifitas penggunaan lahan untuk ternak sapi potong serta membangun kerjasama dengan pemerintah daerah dalam meningkatkan produktivitas usaha ternak sapi potong. Hal ini sesuai dengan pemaparan Rusnan et al (2015) bahwa produktivitas ternak adalah rata-rata bobot badan ternak berdasarkan umur dan jenis kelamin. Produktivitas ternak di pengaruhi oleh 70\% faktor lingkungan dan faktor genetik sekitar 30\%. Di mana faktor lingkungan tersebut, aspek pakan mempunyai pengaruh paling besar yaitu sekitar 60\%, hal ini menunjukkan bahwa walaupun potensi genetik ternak itu tinggi, tetapi pakan mutunya tidak diperhatikan maka produktivitas yang optimal tidak akan tercapai.

Strategi W-T (Weakness-Threat) merupakan strategi pertahanan di mana kelemahan dan ancaman memberikan hambatan baik internal maupun eksternal bagi pengembangan usaha ternak sapi potong. Strategi yang mungkin bisa dilakukan yaitu dengan memperkuat peran lembaga peternakan terutama kelompok tani ternak serta mendorong kebijakan pemerintah dalam pengembangan usaha ternak sapi potong di Kecamatan Lau. Hal ini sesuai dengan hasil penelitian Hajirin (2017) bahwa kelembagaan menunjang keberhasilan pengembangan usaha ternak potong dengan adanya transfer ilmu pengetahuan diantara anggota kelompok. Fasilitas pendukung berupa poskeswan seharusnya dimanfaatkan dengan baik serta daya dukung 24 instansi yang membidangi peternakan dan kesehatan hewan pada ingkat regional Sulawesi Selatan juga memanfaatkan asosiaso bidang sapi potong ditingkat nasional 


\section{$5 \quad$ KESIMPULAN}

Berdasarkan hasil dan diskusi di atas diketahui bahwa hasil matriks IFE dan EFE bernilai positif di mana pada grafik analisis SWOT kedua titik menunjukkan posisi pada kuadran 1 yang merupakan gabungan opportunity dan strenght. Beberapa rekomendasi strategis lahir dari hasil analisis matriks SWOT yaitu berupa peningkatan produktivitas lahan dan ternak, informasi pasar, pelatihan manajemen usaha ternak sapi potong serta dukungan pemerintah dalam hal pelatihan, penyuluhan, pemuliaan ternak/Inseminasi Buatan (IB) serta pemberian fasilitas obat-obatan dan vaksin

\section{ACKNOWLEDMENTS}

Peneliti mengucapkan terima kasih kepada Direktorat Riset dan Pengabdian Masyarakat DIKTI yang telah membiayai penelitian ini pada skema Penelitian Dosen Pemula (PDP) serta dukungan LPPM Universitas Muslim Maros.

\section{DAFTAR PUSTAKA}

Badan Pusat Statistik. (2018). Statistik Daerah Kabupaten Maros. Katalog. 1101002.7308

Hajirin. (2017). Strategi Pengembangan Sapi Potong di Wilayah Pengembangan Sapi Bali Kabupaten Barru. Institut Pertanian Bogor, Bogor.

Karim, I., et al. (2019). Optimalisasi Pengembangan Produk Core Competence pada Usaha Wajik Lokal Mandar sebagai Alternatif Pendapatan. Jurnal Bisnis, Manajemen dan Informatika, Vol 16 No 1.

Mariyono et al. (2010). Rekomendasi Teknologi Peternakan dan Veteriner Mendukung Program Swasembada Daging Sapi (PSDS). Badan Penelitian dan Pengembangan Pertanian

Mayulu, H., Sunarso, Sutrisno, I., Sumarsono. (2010). Kebijakan Pengembangan Peternakan Sapi Potong di Indonesia. Jurnal Litbang Pertanian, 29 (1).

Rangkuti, F. (2009). Analisis SWOT; Teknik Membedah Kaukus Bisnis. PT Gramedia Pustaka Utama, Jakarta.

Rianto, E dan Purbowati, E. (2009). Panduan Lengkap Sapi Potong. Penebar Swadaya, Jakarta.

Rusnan H,Kaunang Ch.L, Tulung YL.R. (2015). Analisis Potensi dan Starategi Pengembangan Sapi Potong dengan Pola Intergrasi kelapa-Sapi di Kabupaten Halmahera Selatan Provinsi Maluku Utara. Jurnak Zootek; 35(2): 187-200 
Priyanto, D. (2011). Strategi Pengembangan Usaha Ternak Sapi Potong dalam Mendukung Program Swasembada Daging Sapid an Kerbau Tahun 2014. Jurnal Litbang Pertanian, 30 (3).

Purnomo, et al. (2017). Strategi Pengembangan Peternakan Sapi Potong Rakyat di Kecamatan Wuryontoro Kabupaten Wonogiri. Buletin Peternakan Vol. 41 (4) : 484494

Tafakresnanto, C. et al. (2016). Atlas Peta Potensi Pengembangan Kawasan Sapi Potong Provinsi Sulawesi Selatan. Kementrian Pertanian

Utari, R.T. (2015). Analisis Kelayakan Usaha Ternak Sapi Potong pada Berbagai Skala Kepemilikan di Desa Samangki Kecamatan Simbang Kabupaten Maros. Fakultas Peternakan, Universitas Hasanuddin

Yusdja, Y. dan Ilham, N. (2006). Arah Kebijakan Pembangunan Peternakan Rakyat. Pusat analisis social ekonomi dan kebijakan pertanian. Analisis Kebijakan Pertanian 4 : 1838 